УДК 377.016.011.3-057.87:81'367

DOI https://doi.org/10.32782/apv/2021.2.10

\title{
Галина КАПТУР
}

кандидат філологічних наук, доцент, дочент кафедри теорії та методики початкової освіти, Волинський національний університет імені Лесі Українки, просп. Волі, 13, м. Луцьк, Волинська обл., Україна, 43025

ORCID: 0000-0001-6989-563X

\section{Наталія ЧАБАН}

магістр факультету педагогічної освіти та соиіальної роботи, Волинський національний університет імені Лесі Украӥнки, просп. Волі, 13, м. Луцьк, Волинська обл., Украӥна, 43025

Бібліографічний опис статті: Каптур, Г., Чабан, Н. (2021). Лінгводидактичні засади формування мовної особистості майбутнього вчителя початкових класів у процесі навчання синтаксису складного речення. Acta Paedagogica Volynienses, 2, 61-67, doi: https://doi.org/10.32782/apv/2021.2.10

\section{ЛІНГВОДИДАКТИЧНІ ЗАСАДИ ФОРМУВАННЯ МОВНОЇ ОСОБИСТОСТІ МАЙБУТНЬОГО ВЧИТЕЛЯ ПОЧАТКОВИХ КЛАСІВ У ПРОЦЕСІ НАВЧАННЯ СИНТАКСИСУ СКЛАДНОГО РЕЧЕННЯ}

\footnotetext{
У статті обтрунтовано теоретичні основи формування мовної особистості майбутнього вчителя початкових класів у процесі навчання синтаксису складного речення української мови; розкрито сутність поняття «мовна особистість майбутнього вчителя початкових класів», «синтаксична компетентність»; представлено елементи методики формування мовної особистості майбутнього вчителя початкових класів. Автори наукової розвідки вбачають, щчо навчання синтаксису здійснюється за допомогою текстоцентричного підходу, щчо реалізується через розроблену систему вправ, у якій чільне місие посідають тексти, щฺо ілюструють культурну спадщиину українського народу, його традиџї, особливості національної ідентичності тощзо. 3'ясовано лінгводидактичні умови формування мовної особистості майбутнього вчителя початкових класів у прочесі навчання синтаксису складного речення, результативність формування якої залежсть від використання ефективних форм, методів, прийомів і засобів навчання. Закиентована увага на рівнях сформованості мовної особистості (вербально-граматичному, когнітивному, прагматичному). Відзначено, шо вербальнограматичний критерій відображає уміння мовної особистості будувати структурно-виправдані синтаксичні конструкиії залежно від їхнього семантичного навантаження, правильно інтонувати речення, визначати їх стилістичні функції; когнітивний - реалізується як уміння мовної особистості породжсувати, розуміти й сприймати мовленнєві висловлення залежно від ӥхньої формально-синтаксичної й семантичної будови, відтворювати за ӥх допомогою ијлісну мовну картину світу на тлі соціально-культурних процесів з урахуванням власної національної ідентичності; прагматичний - свідчить про вміння мовної особистості комунікативно-виправдано використовувати синтаксичні конструкиії відповідно до конкретної мовленнєвої ситуації, залежно від комунікативного наміру й мети спілкування.

Ключові слова: мовна особистість, складники мовної особистості, мовна особистість майбутнього вчителя початкових класів, синтаксис складного речення, види вправ, текст.
}

\section{Halyna KAPTUR}

PhD in Philology, Associate Professor, Senior Lecturer at the Department of Theory and Methods of Primary Education, Lesya Ukrainka Volyn National University, 13 Voli ave., Lutsk, Volyn region, Ukraine, 43025

ORCID: 0000-0001-6989-563X

\section{Natalia CHABAN}

Master of the Faculty of Pedagogical Education and Social Work, Lesya Ukrainka Volyn National University, 13 Voli ave., Lutsk, Volyn region, Ukraine, 43025

To cite this article: Kaptur, H. \& Chaban, N. (2021). Linhvodydaktychni zasady formuvannia movnoi osobystosti maibutnoho vchytelia pochatkovykh klasiv u protsesi navchannia syntaksysu skladnoho rechennia [Linguodidactic foundations of forming the linguistic personality of a future teacher of the primary school in the process of the syntax of a complex sentence]. Acta Paedagogica Volynienses, 2, 61-67, doi: https://doi.org/10.32782/apv/2021.2.10 


\section{LINGUODIDACTICFOUNDATIONS OFFORMINGTHELINGUISTIC PERSONALITY OF A FUTURE TEACHER OF THE PRIMARY SCHOOL IN THE PROCESS OF THE SYNTAX OF A COMPLEX SENTENCE}

In the article the theoretical study of the formation linguistic personality of the future teacher of the primary school in the process of teaching Ukrainian syntax and compound sentence of Ukrainian language; the essence of the notions linguistic personality of the future teacher of the primary school is determined and syntactical competence; elements of methodology are described formation linguistic personality of the future teacher of the primary school. The authors of scientific research see that the teaching of syntax is carried out using a text-centric approach, which is implemented through a developed system of exercises, in which texts illustrate the cultural heritage of the Ukrainian people, its traditions, features of national identity, etc. occupy a prominent place. The lingvodidactic conditions for the formation linguistic personality of the future teacher of the primary school in the process teaching syntax of compound sentence are determined, the result of the formation depends on the usage effective forms, methods, techniques, the criteria are determined. Emphasis is placed on the levels of language personality formation (verbal-grammatical, cognitive, pragmatic). The essence of the proposed technique is to create a system of exercises and tasks (analytical, reproductive, constructive productive and creative character), to realize the textocentric approach to the formation of syntactic skills in the process of mastering phrases, simple and complex sentences. It is noted that the verbal-grammatical criterion reflects the ability of the linguistic person to build structural and justifiable syntactic structures depending on their semantic load, to correctly identify sentences, determine their stylistic functions; cognitive-realized as a skill of linguistic personality to generate, understand and perceive speech expressions depending on their formal syntactic and semantic structure, reproducing them with a holistic language picture of the world against socio-cultural processes, taking into account their own national identity; Pragmatic - indicates the skill of the linguistic person communicative-justifiable to use syntactic structures in accordance with a specific speech situation, depending on the communicative intention and purpose of communication.

Key words: linguistic personality, components of language personality, linguistic personality of future teacher of the primary school, syntax of a complex sentence, types of exercises, text.

Актуальність проблеми. Соціальне замовлення суспільства визначає низку виховних, навчальних і розвивальних завдань, що мають бути реалізовані в освітньому процесі сучасного закладу вищої освіти. Нині виникає необхідність у принципово нових методологічних основах, у використанні інноваційних педагогічних технологій, які б зумовили досягнення поставлених цілей навчання й формування сучасної мовної особистості, яка успішно знаходитиме відповіді на виклики часу й матиме грунтовну фахову підготовку.

Важливим $\epsilon$ не лише опанування студентами професійних знань, методики навчання української мови, а й оволодіння мовленнєвокомунікативними вміннями, розвиток лінгвістичної креативності, стилістичної вправності, на що й спрямовують законодавчі та нормативні документи (Закон України «Про вищу освіту», Державна національна програма «Освіта» (Україна ХХІ століття), Національна доктрина розвитку освіти України в XXI столітті, Державні стандарти початкової, базової і повної середньої освіти).

Аналіз останніх досліджень і публікацій. Проблема формування мовної особистості майбутнього вчителя початкових класів у процесі навчання синтаксису складного речення пов'язана 3 новітніми тенденціями перебудови освітнього процесу, зокрема 3 необхідністю посилення практичного спрямування змісту навчання мови, формування в студентів уміння здобувати інформацію, здійснювати ії обробку та користуватися нею [4].

Різноаспектний аналіз наукових робіт засвідчив, що науці відомі різні підходи до аналізу мовної особистості, які визначають домінантний складник цього поняття: мовна й мовленнєва особистості (А. Горлова, Л. Засєкіна), комунікативна мовна особистість (Л. Лічман, Л. Паламар). Українські науковці також послуговуються поняттям мовної особистості й розглядають його 3 позицій лінгвістики та лінгводидактики (Ф. Бацевич, Л. Мацько, А. Богуш, О. Горошкіна, Н. Дика, М. Пентилюк, Т. Симоненко, І. Хом'як). Цінними є наукові праці T. Гнаткович, I. Горошкіної, С. Омельчука, Л. Пулатової, Л. Струганець, Т. Симоненко та ін., у яких розроблено питання пошуку й упровадження в освітній процес шляхів ефективного формування мовної особистості.

Проблема методики навчання синтаксису української мови розроблена у сучасній лінгводидактиці (О. Біляєв, О. Горошкіна, Н. Дика, О. Караман, С. Караман, С. Омельчук, В. Микитенко, М. Пентилюк, К. Плиско, 3. Столяр, Н. Шульжук). Проте окремі аспекти цієї проблеми залишилися малодослідженими; 
додаткового вивчення потребують питання змісту, форм, прийомів і методів формування мовної особистості майбутніх учителів початкових класів у процесі навчання синтаксису складного речення української мови.

Мета статті. Окреслення шляхів формування мовної особистості майбутніх учителів початкових класів засобами синтаксису складного речення.

Виклад основного матеріалу дослідження. Як свідчить вивчення й аналіз спеціальної літератури, поняття «мовна особистість», що належить до провідних методологічних категорій, увійшло в лінгводидактичний тезаурус нещодавно. Упродовж останніх двох десятиріч активізувалися розвідки, присвячені розробленню продуктивних методик і технологій формування мовної особистості. Л. Струганець визначає поняття «мовна особистість» як комплекс компонентів - психічного, соціального, культурного, етичного та інших, переломлених через мову [7].

Мовна особистість - це наскрізна ідея, що, «як показує досвід іiі аналізу та опису, пронизує всі аспекти вивчення мови й водночас руйнує межі між дисциплінами, які вивчають людину, оскільки неможливо вивчати людину поза іiі мовою» [5, с. 3].

Одним із перших поняття «мовна особистість» увів Г. Богін у праці «Сучасна лінгводидактика», зазначивши, що центральним поняттям лінгводидактики є мовна особистість - людина, яка розглядається з точки зору її готовності здійснювати мовленнєві вчинки.... Мовна особистість характеризується не стільки тим, що вона знає про мову, скільки тим, що вона може 3 мовою зробити [1, с. 3]. Згодом це визначення дослідник доповнив, розглядаючи мовну особистість як людину крізь призму iï «готовності здійснювати мовленнєві вчинки, створювати й приймати витвори мовлення» [1, с. 1].

Таким чином, аналіз науково-педагогічних праць дав підстави для виокремлення в якості складників мовної особистості майбутнього вчителя початкових класів низки компетентностей: мовної, мовленнєвої, комунікативної. I тому першоосновою навчання синтаксису в закладі вищої освіти має стати засвоєння й осмислення студентами понять, що стосуються мовленнєвої діяльності як форми існування мови в усій складності своєї природи та реалізації іiі, функції в налагоджуванні акту спілкування, процес породження мови, мовленнєвої діяльності як продукту цієї діяльності, іiі провідних видів і найголовніших компонентів.

Систематичне вивчення майбутнім учителя початкових класів основ синтаксису зумовлює потребу встановлення зв'язків між здобутими і попередніми знаннями. Засвоєння синтаксичної теорії та основ використання iï буде стабільно ефективнішим, послідовним і структурним за умов:

- навчальна діяльність у закладі вищої освіти має мати активний характер, здійснюватися в спілкуванні й реалізовуватись у своїх основних складниках саме в ньому;

- процес засвоєння знань має здійснюватися одночасно 3 виробленням практичних умінь і навичок, з урахуванням такої риси мовної свідомості, як прагматика, тобто доцільності використання мовних одиниць. У цьому контексті найсуттєвішим здається завдання формування й розвитку прийомів комунікативної діяльності студентів.

На думку С. Омельчука, «основою формування мовленнєво-комунікативних умінь у процесі вивчення синтаксичного матеріалу на заняттях має бути розвиток комунікативної особистості з великим пізнавальним досвідом, високим рівнем комунікативної компетенції, стійким прагненням удосконалювати власне мовлення, наслідувати певний мовленнєвий ідеал» [6, с. 66].

3 огляду на порушену проблему дослідження, постає необхідність у конкретизації поняття «синтаксична компетентність». Синтаксичну компетентність тлумачимо як знання синтаксичних норм і вміле використання цих знань на практиці. Нам імпонує визначення синтаксичної норми С. Єрмоленко, яка зазначає, що «синтаксична норма визначає поєднання й порядок слів у реченні і регулює мовні механізми, які забезпечують цілісність усієї мовної системи» [3, с. 196].

Формування цілісної мовної особистості студента, тобто здійснення навчання синтаксису здійснюється за допомогою текстоиентричного підходу, що реалізується через розроблену систему вправ, у якій чільне місце посідають тексти, що ілюструють культурну спадщину українського народу, його традиції, особливості національної ідентичності тощо. 
Процес формування мовної особистості майбутнього вчителя початкової школи під час навчання синтаксису повинен забезпечуватися використанням форм (фронтальна, колективна, робота в групах, індивідуальна робота), методів (бесіда, спостереження над мовним матеріалом, робота 3 підручником, метод вправ, розповідь викладача), прийомів і засобів навчання (підручники, спеціально дібраний дидактичний матеріал, таблиці, схеми, тексти, словники, відеозаписи, комп'ютерні програми, мультимедійні презентації тощо). 3-поміж методів і прийомів навчання ефективними виявилися: аналіз семантико-синтаксичних відношень у словосполученнях і реченнях; спостереження за функційними особливостями різних синтаксичних конструкцій, їх стилістичною маркованістю в текстах різних стилів і жанрів; моделювання, порівняння, зіставлення, редагування синтаксичних одиниць; продукування власних висловлювань; проблемні, творчі завдання. Успішному формуванню мовної особистості майбутнього вчителя початкових класів сприяє використання й інтерактивних методів: мозкового штурму, дискусії-симпозіуму, ситуативне моделювання, методу проєктів; формування емоційно-ціннісних орієнтацій, тобто усвідомлення, сприйняття, осмислення й застосування знань (робота в парах, малих групах, розігрування ситуації за ролями тощо); організація рефлексії пізнавальної діяльності, тобто систематизація засвоєного матеріалу, застосування здобутих знань і набутих умінь в умовах нової пізнавальної ситуації.

Іерархія рівнів організації та вивчення мовної особистості, визначені Ю.Карауловим, й донині $є$ підгрунтям для лінгвістичних і лінгводидактичних концепцій. Зокрема в процесі навчання синтаксису Н. Дика зауважує, що ці рівні реалізуються так: вербально-граматичний - через уміння мовної особистості будувати структурно-виправдані синтаксичні конструкції залежно від семантичного навантаження їх, правильно інтонувати речення, визначати їхні стилістичні функції тощо; когнітивний - через уміння мовної особистості породжувати, розуміти й сприймати мовленнєві висловлення залежно від їх формально-синтаксичної й семантичної будови, відтворювати за ïx допомогою цілісну мовну картину світу на тлі соціально-культурних процесів з урахуван- ням власної національної ідентичності; прагматичний - через уміння мовної особистості комунікативно-виправдано використовувати синтаксичні конструкції на вимогу конкретної мовленнєвої ситуації, залежно від комунікативного наміру й мети спілкування [2, с. 32].

Під час формування вербально-граматичного рівня мовної особистості майбутнього вчителя початкових класів основне завдання полягає в опануванні студентами мовної й мовленнєвої компетентностей. Перевага повинна надаватися виробленню в студентів таких умінь і навичок: визначати типи синтаксичних одиниць; розрізняти речення різних видів (прості, прості ускладнені, складні); грамотно будувати й використовувати в мовленні словосполучення і речення різних видів; обгрунтовувати вживання розділових знаків за допомогою вивчених правил у різних видах речень; застосовувати на практиці пунктуаційні правила; відшукувати й виправляти помилки на вивчені пунктуаційні правила тощо.

Наприклад, у процесі систематизації знань про складне речення студентам було запропоновано виконати такі завдання:

Завдання 1. Порівняйте прості речення й утворені з них складні. Укажіть, чим вони відрізняються; як уживаються розділові знаки між частинами складного речення.

1. Надворі вже звечоріло. В хаті стояла зелена темрява. - Надворі вже звечоріло, i в хаті стояла зелена темрява. 2. Небо чудово заблишало. Його засіяли зорі. - Небо, яке засіяли зорі, чудово заблищало.

Завдання 2. Зіставте художні описи. Укажіть, чим вони відрізняються; коли надають перевагу складносурядним реченням порівняно $з$ простими. Дослідіть, зі скількох частин складається складносурядне речення, визначте смислові взаємозв'язки між складовими частинами в ньому, вмотивуйте використання сполучників.

1. Ясне сонце почало підніматися десь далеко за лісом. Його червоний світ слався в лісі по снігу. На опушених інеєм високих гілках стрибало його ясне проміння, висвічуючи то жовто-зеленими, то червоно-синіми іскорками.

2. Ясне сонце почало підніматися десь далеко за лісом, $і$ його червоний світ слався в лісі по снігу, а на опушених інеєм високих гілках стрибало його ясне проміння, висвічуючи то жовтозеленими, то червоно-синіми іскорками. 
Завдання 3. Утворіть складні речення вказаних видів, продовжуючи подані частини. Підкресліть граматичні основи, розставте розділові знаки. Прочитайте, правильно інтонуючи:

1. Жодне серйозне питання людство не зможе ефективно вирішити без опертя на науки... (ССР, СПР). 2. В умовах швидкого оновлення знань важливим питанням є підготовка висококваліфікованих науковців (БСР, СПР).

Під час формування когнітивного рівня мовної особистості майбутнього вчителя початкових класів, основну увагу потрібно зосереджувати на удосконалення умінь: виконувати мисленнєві дії - аналіз, порівняння, узагальнення, конкретизацію, синтез, експериментування; формулювати висновки за аналогією; моделювати, робити припущення й добирати переконливі аргументи на підтвердження висловлених тез; критично оцінювати сприйняту інформацію, а також спростовувати хибні твердження, оперуючи відомими уявленнями і поняттями лінгвістичного й позалінгвістичного плану; формуванню парадоксального й дивергентного типів мислення, зокрема вмінь різноаспектно аналізувати проблему в усіх можливих іiї проявах, бачити одразу кілька шляхів розв'язання поставленої проблеми або сприймати проблему шляхом вирішення її тощо.

Наводимо зразки різнорівневих вправ i завдань, які сприяють формуванню дивергентного типу мислення у майбутніх учителів початкових класів:

Завдання 1. Спостереження-дослідження (робота в групах, прийом «ПРЕС»).

1. Прочитайте текст пошепки. До якого стилю мовлення він належить? Чому? 2. Які речення переважають у тексті: прості чи складні? Доведіть (граматичні основи підкресліть). Назвіть сполучникові СР. Розставте пропущені розділові знаки й обгрунтуйте уживання їх. 3.3 якою метою вжито СР у тексті? Зробіть висновок про роль СР у текстах наукового стилю. 4. Перекажіть текст, уживаючи СР.

Корисний винахід

Уявіть велике колесо на обід якого приладнано черпаки. Натиск річкової води крутив колесо у черпаки набиралася вода. Це вже був простий, але універсальний двигун. Спочатку люди його використовували для качання води а згодом - для перемелювання зерна. Так наро- дився водяний млин - річкову воду люди змусили крутити жорна (3 часопису).

Завдання 2. Доберіть із текстів художньої літератури складнопідрядні речення 3 такими компонентами: те... щзо, той... хто, там... де, скрізь... де, так... як, такий... який, стільки... скільки, так... щзо, таким... наче, настільки... щзо. Визначте тип складнопідрядного речення.

Завдання 3. Реконструювання-доведення. 1. Подані речення запишіть у такій послідовності, щоб вони утворили текст. Доберіть до тексту заголовок, що передає його тему. 2. Доведіть, що це висловлювання є розповіддю.

Можна припустити, що частина каші вилилася на вогонь $і$ перетворилася на рум'яний корж. Згодом вони навчилися розтирати його між камінням і варити, тому перший хліб мав вигляд рідкої каші. Давні люди вживали колосся дикої пшениці й жита. Своїм приємним смаком він здивував людину, і хліб почали пекти.

Під час формування прагматичного рівня мовної особистості майбутнього вчителя початкових класів, значну увагу варто приділяти розвитку мовлення, а також вправам і завданням, спрямованим на вдосконалення вмінь студентів дотримуватися вимог правильного пунктуаційного оформлення речень, висловлень, текстів; визначати стилістичну доцільність кожної синтаксичної структури в текстах різних стилів; будувати складні синтаксичні конструкції відповідно до комунікативного завдання, стилю, типу й жанру мовлення; виховування в студентів потреби оволодіти стилістично-синтаксичними нормами української мови. Пропонуємо на заняттях використати наступні види вправ:

\section{Завдання 1.}

Прочитайте слова Ліни Костенко. Поясніть, як ви їх розумієте.

I не знецінюйте коштовне,

Не загубіться у юрбі.

Не проміняйте неповторне

На сто ерзаиів у собі!

Занотуйте тезово свої думки та наведіть переконливі аргументи. Підкріплюйте їх прикладами 3 життя, художньої літератури тощо. Відповідь запишіть у вигляді власного висловлювання, вживаючи складні синтаксичні конструкції.

Завдання 2.Уявіть ситуацію: ви в колі нових друзів. Вони ніколи не були у вашому краї. Як би ви розповіли їм про своє місто, село, захо- 
пивши їхню уяву? Використовуйте складнопідрядні речення різного типу.

Завдання 3. Складіть і розіграйте міні-діалог, комунікативною метою якого $є$ поділитися 3 другом (подругою) цікавою історією (прочитаною чи побаченою), що справила на вас велике враження. У діалозі дотримуйтесь правил спілкування і використайте 2 речення (на вибір):

Ти читав (дивився фільм) про те, як ...? Ти уявлясш, як (що) ... ? Ніколи не думав (думала), що ... . Я вражений (вражена) тим, щзо ... . Мені сподобалося, щзо (як) ...

Завдання 4. Дослідження-пошук із творчокомунікативним завданням. Запишіть текст, розставляючи розділові знаки. Визначте його тему й основну думку. Доберіть заголовок. Поміркуйте, чи можна вважати його текстом? Свою думку обгрунтуйте. Доповніть поданий текст, увівши елементи роздуму.

Давні греки тих хто погано говорив по-грецьки вважали варварами. У иьому сенсі у нас суспільство майже всуиіль варварське ні справжньої украйнської мови ні російської. То якої ж другої державної прагнуть так звані «російськомовні»? Чи відомо їм щзо їхню «другу державну» в західних наукових виданнях вже офіиійно називають суржиком? Явище вимагає терміна і воно його одержало.

Справді «так історично склалося». Нечуваний тиск русифікації призвів до патологічних мутацій. Отже потрібна не апологія цих мутаиій а їхня діагностика і лікування. Мова це також обличчя народу воно тяжко спотворене. Нинішня мова громадян та політиків не додає Украӥні престижу (За Л.Костенко).

Форми, методи, засоби формування мовної особистості майбутніх учителів початкових класів засобами синтаксису складного речення повинні якомога повніше враховувати інтереси, здібності, запити особистості, бути спрямованими на формування професійно важливих якостей майбутніх вчителів початкових класів.

Висновки і перспективи подальших розвідок цього питання.

Опанування синтаксису складного речення української мови майбутніми вчителями початкових класів на основі інтеграції педагогічних підходів до формування мовної особистості сприяє підвищенню рівня знань теоретичного матеріалу 3 синтаксису, загальної культури мовлення студентів, готовності до адекватного вибору мовленнєвих одиниць відповідно до комунікативної мети й ситуації спілкування, формуванню усвідомленого ставлення до української мови як культурної, інтелектуальної й духовної цінності, розвитку інтелектуальнотворчих здібностей, формуванню мовної, мовленнєвої, соціокультурної й комунікативної компетентностей (цілісної мовної особистості). Перспективним, зокрема, вважаємо розроблення положень щодо особливостей формування мовної особистості майбутнього вчителя початкової школи засобами інших розділів мовознавства.

\section{ЛІТЕРАТУРА:}

1. Богин Г.И. Модель языковой личности в ее отношении к разновидностям текста: автореф. дис. док. филол. наук: 10.02.19 - Теория языка. Ленинград, 1984. 31 с.

2. Дика Н.М. Формування лінгвістичної термінології в учнів основної школи під час вивчення граматики. Studia methodologica. Вип. 31. 2011. С. 29-33.

3. Єрмоленко С.Я., Бибик С.П., Коць Т.А. та ін. Літературна норма і мовна практика: монографія. Ніжин : ТОВ «Видавництво «Аспект-Поліграф». 2013. 320с.

4. Калюжка Н.С. Формування мовної особистості сучасного учня: пошук підходів. Рідна школа. 2020. № 2-4. C. 59-64.

5. Караулов Ю.Н. Русский язык и языковая личность. Москва : Наука, 2006. 263 с.

6. Омельчук С.А. Дослідницькі завдання з мови як ефективний засіб формування компетентного мовця. Українська мова і література в шкколах України. 2017. № 7-8. С. 66-69.

7. Струганець Л.В. Теоретичні основи культури мови: навч. посібник для студ. філолог. факультетів вузів України. Тернопіль, 1997. 96 с.

\section{REFERENCES:}

1. Bogin, G.I. (1984). Model yazykovoy lichnosti v ee otnoshenii k raznovidnostyam teksta: avtoref. dis. dok. filol. nauk: 10.02.19 - Teoriya yazyka. Leningrad, 31 [in Russian].

2. Dyka, N.M. (2011). Formuvannja linghvistychnoji terminologhiji v uchniv osnovnoji shkoly pid chas vyvchennja ghramatyky. Studia methodologica, 31, 29-33. [in Ukrainian]. 
3. Jermolenko, S.Ja., Bybyk, S.P., Kocj, T.A. ta in. (2013). Literaturna norma i movna praktyka: monoghrafija. Nizhyn: TOV "Vydavnyctvo «Aspekt-Polighraf". 320. [in Ukrainian].

4. Kaljuzhka, N.S. (2020). Formuvannja movnoji osobystosti suchasnogho uchnja: poshuk pidkhodiv. Ridna shkola, 2-4, 59-64. [in Ukrainian].

5. Karaulov, Yu.N. (2006). Russkiy yazyk i yazykovaya lichnost. Moscow: Nauka, 263 [in Russian].

6. Omeljchuk, S.A. (2017). Doslidnycjki zavdannja z movy jak efektyvnyj zasib formuvannja kompetentnogho movcja. Ukrajinsjka mova i literatura v shkolakh Ukrajiny, 7-8, 66-69 [in Ukrainian].

7. Strughanecj L.V. (1997). Teoretychni osnovy kuljtury movy: navch. posibnyk dlja stud. filologh. fakuljtetiv vuziv Ukrajiny. Ternopilj [in Ukrainian]. 